\title{
Social work education \\ in Canada, England \\ and South Africa: \\ A critical comparison \\ of undergraduate \\ programmes
}

\author{
Gary Spolander \\ Coventry University, UK
}

\section{Annie Pullen-Sansfacon}

Unlversité de Montréal, Canada

\section{Marion Brown}

Dalhousle University, Canada

\section{Lambert Engelbrecht}

Stellenbosch University, South Africa

\begin{abstract}
Globalized labour mobility has led to questions regarding the degree to which social work education in one country can be applicable to practice in another. This paper examines social work education programmes and practice contexts in South Africa, England and Canada as examples through which to examine this question.
\end{abstract}

\section{Keywords}

global migrations, international, labour mobility, programme comparison, social work education

Corresponding author: Marlon Brown, Dalhousle Unlversity, Sulte 320I, I 459 LeMarchant Street, Hallfax, Nova Scotla, B3H 3P8, Canada.

Emall:Marion.Brown@dal.ca 


\section{Introduction}

In the current context of globalization, migratory movements are occurring across the world in unprecedented numbers. In addition, labour mobility among professionally-educated practitioners from a range of academic disciplines is also on the rise, presenting unique challenges to educational institutions and discipline-specific regulatory bodies. This paper explores the issues inherent in the migration of social work practitioners with regard to their move from professional education in one national context to professional practice in another. Specifically, this paper examines social work education models for practice in England, South Africa and Canada with a view to understanding how these systems prepare social workers for international migration in their professional capacity. The authors begin with an overview of the social welfare context in each country and then detail the methodology used for the comparison herein. Next, the authors review systems of accountability, admission to programmes, practice learning, professional suitability, and relationship to the professional body across the three countries. The paper concludes with implications drawn from analysis of the three social work education models.

\section{Setting the context}

Among the many concurrent agendas of globalization, the development of policies and multi-lateral agreements to facilitate labour mobility among the professions has become an increasing priority. Social work educational programmes have taken up the cause to prepare students for international migration as well as facilitate international exchange experiences for students returning to their home countries. As a result there are challenges to curriculum, pedagogy and assessment (Razack, 2002). For example, the document 'Global Standards for the Education and Training of the Social Work Profession' (International Association of Schools of Social Work [IASSW] and International Federation of Social Workers [IFSW], 2004) identifies universal values that propose a consensus around key issues, roles and purposes of social work internationally. This document acknowledges a need for flexibility in assessment of social work education and its application across cultural and structural contexts, and offers a starting point in the dialogue regarding the impacts of labour mobility on practice. The concept of universal standards attempts to ensure a common level of expectation in relation to social work education globally; it offers a framework to recognize transnational mobility of social workers and acknowledge the impact of global events on local practice (Lyons, 2006). At the same time, these 
standards cannot ensure standardized education and practice: due to the diversity of spoken languages internationally, the differences in economic and geographical situations, and the varied cultural norms in place, global standards are not always internationally relevant, which makes their application challenging (Healy, 2004; Yip, 2004). Furthermore, not all schools offering social work programmes develop their curriculum based on the 'Global Standards': the findings of a membership survey commissioned by the IFSW in 2005 showed that out of the 28 countries that responded, between 27 and 40 percent of the schools did not have all the required course content as recommended therein (Baretta-Herman, 2008).

This paper examines specific components of social work education programmes in South Africa, England and Canada in an effort to exemplify the tension between the call for universal standards of social work education and the unique socio-political contexts of each country.

\section{Socio-political contexts of social welfare in South Africa, England and Canada}

In all three countries, historically and rhetorically, the primary target group of social work is vulnerable and marginalized sectors of society. Integrated social work services are delivered on levels of prevention, early intervention, statutory, residential and alternative care. Within these systems, the profession of social work has long been part of a system promoting the development and social well-being of individuals, families, groups and communities though a range of service providers, such as the government, non-governmental organizations, community-based and faith-based organizations and private sector entities. Paradoxically, social work in England and Canada has simultaneously long been critiqued for its benevolent imperialism in the delivery of its services, as described later.

The legacies of colonization and apartheid have resulted in a history of inequality and violations of human rights in South Africa. These have been key features in the development of its system of social welfare and social work in particular after the country's first democratic elections of 1994. Central to democratic and citizens' rights is the South African Bill of Rights, which guarantees rights under the Constitution of the Republic of South Africa (Republic of South Africa [RSA], 1996), including the right to education, healthcare, political and civil rights and social security. These rights are judicially enforceable and underpin a social development approach to social welfare that supports social and economic development, democracy and participation in welfare (RSA, 1997). The constitution obligates the state to bestow social rights and serves as the basis for 
the country's developmental social welfare trend, transcending the residual welfare approach of the past.

England, in contrast, has embraced models of provision derived from new public management, which as a global movement has been motivated by neo-liberal theory and economic ideas of improving efficiency (Christensen and Lægreid, 2007). Thus in England, market ideology and management solutions are seen as the motivating factors in improving and increasing efficient administration of the welfare state and the interlined ideas that professionals may disable the 'clients' that they should be assisting. For example, Harris (2003) identifies that the Seebohm Report (1969) did not appear to benefit service users as much as other front-line services from whom the majority of referrals were received. Thus social service departments responded to the needs of community-based agencies rather than developing and establishing their own preventative and casework functions. The majority of social work services is provided within a statutory environment, although many services are increasingly commissioned by the government local authority from small and large independent providers who now provide many services on their behalf. The independent sector is also therefore an important provider of social work services, and their services are usually more preventative than those of the statutory sector.

Finally, while Canada is a country that often enjoys positive international assessment, with its reported comfortable standard of living, social programmes, and mix of urban and rural lifestyles, analysis of social care soon reveals evidence of a staunch conservative ideology in shaping the direction of social welfare and social work. As with England, neo-liberalism's focus on individual rights and responsibilities provides the foundation for a prevailing discourse that essentially blames people for the structural obstacles they encounter. In addition, progressively since 1996, federal and provincial governments have continued to devolve responsibility for social welfare programming by contracting out to non-profit and private agencies, rolling back the reach of state-sponsored social care. For social workers, the incongruence of subscribing to a code of ethics which upholds social justice and emancipation of the oppressed, while working within an ideology that individualizes and pathologizes social issues, is an increasingly untenable dilemma (Mullaly, 2006).

\section{Methodology: Comparative document analysis}

The methodology for this project was based on a comparative analysis of documents. This method was selected as a means of providing detailed information on the different social work education models in the three countries. 
Institutional visits and analysis of documents relevant to each country were undertaken between January and May 2009.

A comparison of documents based on a qualitative content analysis methodology was selected because the information needed was already available in the public sphere (Neuman, 2007); that is, all three countries had published standards and requirements for social work education. While content analysis is usually related to a more quantitative approach to document analysis, qualitative content analysis involves going

beyond merely counting words to examining language intensely for the purpose of classifying large amounts of text into an efficient number of categories that represent similar meanings. .. . Qualitative content analysis is defined as a research methodology for the subjective interpretation of the content of text data through the systematic classification process of coding and identifying themes or patterns. (Hsieh and Shannon, 2005: 1278)

The authors defined the following inclusion and exclusion criteria based on the requirements for validity provided by Scott (1990), for authenticity, credibility, representativeness and meaning.

- Documents produced by recognized professional associations

- Documents produced by recognized validating and/or regulating body

- Documents produced by accredited schools of social work

- Information relating to Bachelor of Social Work or equivalent

Conventional Content Analysis (Hsieh and Shannon, 2005) was used to define the categories and proceed to coding of the documents. Conventional Content Analysis is an approach used in studies aimed at describing phenomena where theory, research and literature are limited (Hsieh and Shannon, 2005). Indeed, there are a limited number of studies exploring the migration of social workers; those that exist fail to examine education models and curriculum (see for example Hussein et al., 2008). One study compares social work practice in different countries (Daley, 2003); however, comparative analysis of social work requirements across national contexts is scarce. Hsieh and Shannon (2005) explain that one challenge of Conventional Content Analysis is failing to develop a complete understanding of the context, thus failing to identify key categories; this was counteracted by undertaking the data analysis collaboratively, through a series of university visits in the three countries. Social work researchers from Coventry University (England), Dalhousie University and Université de Montréal (Canada), Stellenbosch University and Nelson Mandela Metropolitan University 
(South Africa) met on several occasions, in each location, to examine the differing programme specifications. Through discussions, analysis of local contexts and a thorough examination of the key documents selected through the inclusion and exclusion criteria, the team determined the following categories for analysis:

- Systems of accountability

- Admission to programmes

- Practice learning

- Suitability

- Codes of practice

- Relationship to professional body

The following section examines the research findings using the six aforementioned categories as a guide to the discussion.

\section{Comparison of the social work education models}

\section{Systems of accountability in social work education}

Each country is accountable to a national body in the development and delivery of social work education. In England these include the Requirement for Social Work Degree (Department of Health, 2002); the Quality Assurance Agency Benchmark for Social Work (2000); the National Occupational Standards (QAA, 2007; Qualifications and Curriculum Development Agency, 2002); and the General Social Care Council Code of Practice (GSCC, 2002). In South Africa, educational programmes are accountable to the South African Council for Social Service Professions (RSA, 1978) and the South African Qualifications Authority (RSA, 1995, 2003). The Canadian Association for Social Work Education (CASWE) determines the Standards of Accreditation (CASWE, 2008), to which all social work education programmes must adhere.

In each of the three countries, social work education is offered as a generalist degree, meaning that, upon completion, students are prepared to work with client groups in various settings. The undergraduate degree ranges from two to four years of full-time study, and specialization can be achieved through post-graduate study. In England and Canada, both undergraduate and postgraduate social work degrees can lead to registration with the regulators of the profession. In England, the regulator is the GSCC; in Canada regulation is a provincial matter. In South Africa, the profession is regulated through the South African Council of Social Service Profession (SACSSP). While comparisons in terms of degree requirements is quite 
straightforward, the differences in what constitutes qualification, and, in Canada, the fact that legislation of the profession is a provincial matter, makes direct comparison across the three countries a challenge.

\section{Admission to programmes}

Social work programme admission criteria and processes vary considerably across the three national sites. In England, the admission standard is set by the academic qualification awarded in a specified subject, an examination generally taken by students at 16 years of age. The academic admission requirement for social work programmes in England depends upon the institution. However, all programmes must at least satisfy the minimum requirements set by the Department of Health's requirements for social work training (Department of Health, 2002), which requires that each candidate must have obtained the equivalent of a $\mathrm{C}$ grade in both Mathematics and English in accordance with the General Certificate of Secondary Education (GCSE) and an individual or group interview prior admission. All incoming students must be able to communicate proficiently in spoken and written English. Furthermore, universities must 'satisfy themselves that all entrants have the capability to meet the required standards by the end of their training and that they possess appropriate personal and intellectual qualities to be social workers' (Department of Health, 2002). Each institution is left to develop the mechanism for this assurance. Finally, stakeholder representative(s) must be included in the selection process, although each university can determine the means for this inclusion.

Social work is offered at all universities in South Africa, which use a National Qualification Framework (NQF), as legislated in the South African Qualifications Authority Act (RSA, 1995), to set their admissions criteria. The NQF is a unified system for recognizing and organizing qualifications across a range of professions, a structure also used in several other countries, including England. It is a set of guidelines according to which learner achievements are registered, in order to recognize national standards of acquired skills and knowledge in an integrated and coordinated fashion. For admission into social work programmes in South Africa, applicants must have the required equivalent of a NQF level set by the admission requirements for university study, which is based on obtaining a National Senior Certificate and achieving an aggregate determined by the universities in four subjects designated for university study. Some universities expect applicants to write an access test, specified for the programme to which they wish to apply.

In Canada, the CASWE's Standards of Accreditation states that each school of social work in the country must clearly state the academic and 
professional entrance requirements in admission documentation, including any provisional requirements in keeping with the mission and mandate of the particular school. Most undergraduate programmes require at least one year of university study, at a minimum average grade of 70 percent, for consideration. The expectation of competence in the English language is set at the university level, not the level of the specific academic programme.

\section{Practice learning}

Practice learning, also known as field education, refers to the focus on integration of theory and practice that occurs when students are placed for a specified period of supervised social work practice in a social service agency. Several components of practice learning have been compared among the three identified countries. These include: number of hours required; preparations for placement; requirements of placement settings; contact with service users; and qualifications of practice assessors and assessment of practice learning.

The English system for social work education requires 200 assessed days of practice over the course of the undergraduate degree. At approximately 7.5 hours per day, this equates to 1500 hours of assessed practice learning. There is no national agreement on the number of hours required for practice education in South Africa. The Association of South African Social Work Education Institutions (ASASWEI) recently did an audit in the country and found that both the duration and the nature of field education vary considerably across institutions. The Canadian standard is 700 hours at the undergraduate level, though assessment of prior learning or experience may reduce this requirement, with a base amount still required to be undertaken (CASWE, 2008).

Preparations for the practice learning courses normally include criminal records and child abuse registry checks for England and Canada. In both countries, the respective registry records only convictions. In the case of an existing criminal record, Canadian documentation specifies that prior convictions may render the student ineligible for certain practice learning sites (based on the criteria of said sites) as well as for licensure after graduation. In England some criminal convictions will render the student ineligible to register with the GSCC and therefore to undertake the social work course in the first place. In South Africa, students must be registered with the SACSSP annually from the time of their second academic year onward. While criminal record checks are not required for South African universities, students are required to declare any conviction by a court of law or legal proceedings pending against them when they register as a social work student. Registration as a student social worker carries the same requirement for professional conduct and code of ethics and rules as for qualified social workers. 
While all three countries set requirements with regard to the context of practice learning, the specifications vary. In England, students must undertake placements in two distinct social service delivery models in their practice learning course, one of which must be a statutory environment. This distinction is not made for the South African or Canadian contexts. However, the South African Integrated Service Delivery Model (RSA, 2006) and CASWE Standards of Accreditation require that practice learning should include opportunities for students to be involved in direct and indirect interventions within conditions that allow for the analysis of systematic oppressions experienced by service users. The Canadian documentation makes particular note of practice learning sites which are relevant to the geographical location, an inclusion which recognizes the vast regional disparities experienced in terms of economics, access to resources, experiences of indigenous populations, and urban-rural tensions.

With regard to contact with service users, the English system requires that students work with two distinct populations in order to be prepared for general social work practice. In neither South Africa nor Canada is there a provision for placement settings with particular service user populations. Further, in Canada, direct practice is not equated with direct practice with service users, such that placements in policy development and research are considered equally valid as those sites that work frontline with service users.

In England, practice assessors must be undertaking or have completed a GSCC-recognized practice learning course offered by the universities that grant the social work degree. The title of this qualification has recently changed from 'Practice Teaching Award' to a single course entitled 'Enabling Others', reflecting a pedagogical shift from teaching students to creating the conditions for self-learning. ${ }^{1}$ In South Africa, practice learning assessors must be registered as professional social workers with the SACSSP. Only registered social workers may function as supervisors during the education of student social workers. In Canada, practice teachers supervising a bachelor level student must hold a minimum Bachelor of Social Work (BSW); however, if there is a placement setting considered appropriate to the purposes of the practice learning course within which there is no social worker employed on site, arrangements are made to provide an off-site practice assessor who is a qualified social worker. Field instructors at the Bachelor of Social Work (BSW) level should possess, at a minimum, a BSW degree from a recognized professional programme and two years of social work practice experience after graduation. Canadian Schools of Social Work are required to ensure that field supervisors meet the further criteria as outlined in the Canadian Association for Social Work Education's Standards of Accreditation (CASWE, 2008). The practices in South Africa and Canada therefore differ from that of England in that the English system does not 
require the practice assessor to be a qualified social worker other than for the final practice learning placement. Indeed, with regard to the first placement, any health or social care professional can undertake the 'Enabling Others' course and then act as a practice assessor for social work.

In each country the function of student assessment in the practice placement includes a faculty member as well as the placement-based practice teacher. The faculty member is responsible for communicating the university standards and scholarly expectations upon the student, as well as to ensure academic regulations are followed in the event of concerns regarding failure of the course or professional unsuitability.

The National Occupational Standards (Qualifications and Curriculum Development Agency), a set of benchmarks to assess performance, is used as the basis for assessment of practice learning in England, with the student responsible to compile evidence to substantiate the assessment. This evidence includes examples and testimonies on each of the six National Occupational Standards as well as the sub-standards of each. Similarly, in South Africa students must demonstrate achievement according to national standards, also referred to as exit level outcomes. These exit level outcomes include fundamental, core and elective components. In Canada, students are assessed according to the course outcomes as well as an individualized learning agreement developed at the outset of the practice placement and to which the student, practice assessor and faculty have agreed. In summary, while in South Africa and England the assessment is measured based on external criteria, the Canadian system allows for personalized learning goals in concert with the course objectives.

\section{Suitability for professional practice}

Regulations for professional suitability for social work education and practice are maintained at the university level for South Africa and Canada. In England these regulations are shared between the university and the GSCC. In South Africa, suitability is determined based fully on academic merit; it is assumed that 'unsuitable' students will not pass the modules during the course of the social work programme. In England, social work programmes must assure the institutions that students have demonstrated the appropriate knowledge and skills of the profession and have met the requirements as stipulated by the Department of Health. This is assured through rigorous assessment of the student's portfolio (academic work and practice learning assessment) at the final period of study, a process undertaken jointly by the university and the GSCC. In Canada, assessment of professional suitability refers not to the academic record but to adherence with the national code of 
ethics. Following due process the student may be assessed as unsuitable for the profession of social work.

\section{Relationship to professional body}

In England and South Africa, and some provinces in Canada, the designation of 'social worker' is a protected title and can only be used by those who are qualified to the relevant regulatory standard and are registered with the professional regulator. These are the GSCC in England, the SACSSP in South Africa and the relevant provincial body in Canada. In England all social work students register with the professional body, the GSCC, and are required to maintain registration for the remainder of their studies. In addition students are encouraged to join and therefore abide by the codes of ethics established by the British Association of Social Workers. However, this code is not legally binding as is the GSCC code and therefore is aspirational in nature.

In South Africa the SACSSP maintains the 'Policy Guidelines for Course of Conduct, Code of Ethics and the Rules for Social Workers' which forms part of the Social Services Professions Act (RSA, 1978). South African students register with the SACSSP before the commencement of the second year of their degree and some universities expect students to take a public oath to uphold the SACSSP code of ethics.

In Canada regulation for practice is a provincial matter and therefore regulatory requirements vary across the country, although social work is a licensed profession in each province except for the territory of Nunavut. For example, in Nova Scotia, social workers are required to register when they complete their education and are entering practice; a two year candidacy period is required wherein the social worker meets monthly with a registered social worker and provides quarterly reports to the provincial regulatory body. In contrast, in Ontario, social work graduates can apply for registration directly following graduation with the social work degree. In Canada the code of ethics for social workers is held at the national level and adhered to by most provincial professional associations.

\section{Implications for the migration of social workers}

While there are some similarities among the programmes reviewed earlier, important differences have also been noted which can lead to confusion and create a sense of displacement among social workers and social work students who are educated in one setting and seek to practice in another. For example, within Canada alone, assessment of foreign credentials differs from one province to another, with British Columbia contracting out the 
examination of candidate files, Nova Scotia subscribing to the assessment process offered by the Canadian Association of Social Workers, and Quebec's provincial regulatory body undertaking the evaluation themselves. In England and South Africa assessment of foreign credentials is the purview of the professional regulator.

While on the one hand these varied processes can be seen to meet local demand, on the other hand some professional bodies are calling for universalized procedures that reconcile standards and practices transnationally (Beddoe and Duke, 2009). Indeed, some countries have begun to sign bilateral agreements that allow for a social worker qualified in one country to practice in the other without having to go through a formal process of equivalence, for example in the case of the France-Quebec agreement (Ordre Travailleurs Sociaux et Thérapeutes Congugaux du Québec [OTSTCFQ] and Ministère du travail, des relations sociales, de la famille, de la solidarité et de la ville Français [MTRFSVF], 2009). Other countries have begun to recognize social work qualifications from another country, for example the General Social Care Council in England will recognize social work qualifications earned in Canada if the university where the candidate has qualified is accredited by the Canadian Association for Social Work Education (GSCC, 2009). Given the momentum of globalized movement among educated professionals, we argue that it behoves social work educators and regulators to implement a system that reconciles the discrepancies and conceptualizes a social work identity that is transnational in scope. Universal criteria for social work education would facilitate the mobility of the workforce while ensuring that equivalent standards have been achieved regardless of the country of study. However, criteria and standards do not address the need for an inclusive and rigorous process for determining equivalence. For while the 'Global Standards for the Education and Training of the Social Work Profession' (IASSW and IFSW, 2004) articulate criteria, not all countries have integrated them in their curricula (Baretta-Herman, 2008). Indeed, Johnson and Wolf (2008) caution that such a policy may not encourage the development of transferable skills, but rather may simply instate minimum standards. Walsh and colleagues (2009) also note that minimum standards, even if implemented, may still be interpreted differently from one country to another and, therefore, not guarantee that minimum standards are reached. Finally, as social work educators committed to analytical and progressive social work pedagogy and practice, it is difficult to endorse standards that are 'minimum', given the potential implications of minimally prepared practitioners on the lives of service users.

We are left, then, with a somewhat classic tension between modernism's pull toward standardized structures that are applicable across time and space, and postmodernism's push for prioritizing local contexts and 
cultures. On the one hand the promise of modernism's influence is a universal agreement on what constitutes best practice in social work education, with measurement standards to ensure best practice in social work delivery, for all service users regardless of the country within which social workers are trained. This direction is appealing, given its congruence with upholding the best interests of the service user and protection from poor social work practice. On the other hand, one of the effects of postmodernism has been to raise collective consciousness to the social construction of knowledge, custom and practice, historically and contextually situated. Social work education and practice are well familiar with this tension, given its commitment to uphold social justice for all and its acknowledgement that the requirements and expressions of social justice necessarily differ across peoples and communities. Developing a transnational system for recognition of social work credentials needs to attend to criteria and standards as well processes for working across contexts, situational needs and discrepancies.

\section{Conclusion}

In the context of global migratory patterns, devising equivalent standards for education and qualification for social workers is clearly a valid task. At the same time, this paper makes clear the challenges inherent in doing so, given unique systems of categorization, distinct terminology and the antecedent events which have led to particular national priorities. This paper has reviewed social work educational processes in England, South Africa and Canada in an effort to explore the work ahead, should these nations consider mitigating the difficulties for social workers migrating between them. The authors advocate for the conceptualization of a transnational social work to lay the groundwork for transnational criteria, standards and processes to facilitate the migration of social work professionals who will continue to be on the move for professional, personal and political reasons.

\section{Note}

1. While fully relevant, a discussion of issues related to the pedagogical orientation of Practice Teachers lies beyond the scope of this paper.

\section{References}

Barretta-Herman, A. (2008) 'Meeting the Expectations of the Global Standards: A Status Report on the IASSW Membership', International Social Work 51: 823-34. 
Beddoe, L. and J. Duke (2009) 'Registration in New Zealand Social Work: The Challenge Of Change', International Social Work 52(6): 785-97.

Canadian Association for Social Work Education (CASWE) (2008) 'Standards for Accreditation'. Retrieved from www.caswe-acfts.ca/en (accessed 30 October 2009). Canadian Association of Social Workers (2005) 'Social Work Code of Ethics'. Retrieved from http://www.casw-acts.ca (accessed 30 October 2009).

Christensen, T. and P. Lægreid (2007) Transcending New Public Management. Aldershot: Ashgate.

Daley, J.G. (2003) 'Military Social Work: A Multi-country Comparison', International Social Work 46(4): 437-48.

Department ofHealth (2002) 'Requirements for Social Work Training'. London: HMSO. Retrieved from http://www.dh.gov.uk/en/Publicationsandstatistics/Publications/ PublicationsPolicyAndGuidance/DH_4007803 (accessed 22 November 2010).

General Social Care Council (GSCC) (2002) Code of Practice for Social Care Workers and Code of Practice for Employers of Social Care Workers. London: General Social Care Council.

General Social Care Council (GSCC) (2009) 'Country Assessment Guidance: Canada'. Retrieved from http:/www.gscc.org.uk/page/205/Canada.html (accessed 23 November 2010]).

Harris, J. (2003) The Social Work Business. London: Routledge.

Healy, L.M. (2004) 'Standards for Social Work Education in the North American and Caribbean Region: Current Realities, Future Issues', Social Work Education 3(5): 581-95.

Hsieh, H. and S.E. Shannon (2005) 'Three Approaches to Qualitative Content Analysis', Qualitative Health Research 15(9): 1277-88.

Hussein, S., J. Manthorpe and M. Stevens (2008) International Social Care Workers: People and Places in an Exchangeable Time. Paper presented at Joint Social Work Education Conference, 3 July 2008, Cambridge.

International Association of Schools of Social Work (IASSW) and International Federation of Social Workers (IFSW) (2004) 'Global Standards for the Education and Training of the Social Work Profession'. Adelaide, Australia. Retrieved from www.ifsw.org (accessed 11 September 2009).

Johnson, S. and A. Wolf (2008) 'Qualifications Recognition Across Borders'. Paper presented at the annual conference of the International Association for Educational Assessment, Cambridge, September 2008. Retrieved from http://www.iaea2008.cambridgeassessment.org.uk/ca/digitalAssets/180455 Johnson__Wolf_IAEA2008_.pdf (accessed 22 November 2010).

Lyons, K. (2006) 'Globalization and Social Work: International and Local Implications', British Journal of Social Work 36: 365-80.

Mullaly, B. (2006) The New Structural Social Work: Ideology, Theory, Practice. Toronto: Oxford University Press. 
Neuman, W.L. (2007) Basics of Social Research, 2nd edn. Essex: Pearson.

Ordre Travailleurs Sociaux et Thérapeutes Congugaux du Québec (OTSTCFQ) and

Ministère du travail, des relations sociales, de la famille, de la solidarité et de la ville Français (MTRFSVF) (2009). 'Arrangement en vue de la reconnaissance mutuelle des qualifications professionnelles entre l'Ordre professionnel des travailleurs sociaux du Québec et le ministre du travail, des relations sociales, de la famille, de la solidarité et de la ville Français'. Retrieved from http://www. immigration-quebec.gouv.qc.ca/publications/fr/arm/ARM-travailleurs-sociaux. pdf (accessed 22 November 2010).

Quality Assurance Agency for Higher Education (QAA) (2000) 'Social Policy and Administration and Social Work. Subject Benchmark Statements'. Gloucester: Quality Assurance Agency for Higher Education. Retrieved from http://www. qaa.ac.uk/academicinfrastructure/benchmark/honours/socialwork.pdf (accessed 22 November 2010).

Quality Assurance Agency (QAA) (2007) 'Subject Benchmark Statement: Social Work'. Draft for consultation, September 2007. Retrieved from http://www.qaa. ac.uk/academicinfrastructure/benchmark/statements/drafts/SocialWork07.asp (accessed 23 November 2010).

Qualifications and Curriculum Development Agency, The (2002) 'Skills for Care'. The National Occupational Standards for Social Work. Retrieved from http:// www.skillsforcare.org.uk/developing_skills/National_Occupational_Standards/ social_work_NOS.aspx (accessed 23 November, 2010).

Razack, N. (2002) 'A Critical Examination of International Student Exchanges', International Social Work 45(2): 251-65.

Republic of South Africa (RSA) (1978) South African Council for Social Service Professions. Ministry for Social Development. Social Service Professions Act (100 of 1978) (amended National Welfare Act [Act 100 of 1978]). Pretoria: Government Printer.

Republic of South Africa (RSA) (1995) South African Qualifications Authority Act (Act 58 of 1995). Ministry of Education. Government Gazette 364: No. 16725 (4 October). Pretoria: Government Printers.

Republic of South Africa (RSA) (1996) 'Constitution of the Republic of South Africa'. Retrieved from www.info.gov.za/documents/constitution/index.htm (accessed 30 October 2009).

Republic of South Africa (RSA) (1997) White Paper for Social Welfare. Ministry of Welfare and Population Development. Notice 1108 of 1997, Government Gazette 386: No. 18166 (8 August). Pretoria: Government Printers.

Republic of South Africa (RSA) (2003) South African Qualifications Authority. Qualification: Bachelor of Social Work. Government Gazette 452: No. 24362 (7 February). Pretoria: Government Printers. 
Republic of South Africa (RSA) (2006) Integrated Service Delivery Model Towards Improved Social Services. Department of Social Development. Pretoria: Government Printers.

Scott, J. (1990) A Matter of Record: Documentary Sources in Social Research. Cambridge: Polity Press.

Seebhom Report (1969) London: Association of Municipal Corporations, County Councils Association.

Walsh, T., G. Wilson and E. O'Connor (2009) 'Local, European and Global: An Exploration of Migration Patterns of Social Workers into Ireland', British Journal of Social Work 1-18: doi: 10.1093/bjsw/bcp141

Yip, K. (2004) 'A Chinese Cultural Critique of the Global Qualifying Standards for Social Work Education', Social Work Education 23(5): 597-612.

\section{Author biographies}

Gary Spolander is Principal Lecturer in Health and Social Care Management at Coventry University in England.

Annie Pullen-Sansfacon is an Assistant Professor at the School of Social Work at Université de Montréal, Canada.

Marion Brown is an Assistant Professor in the School of Social Work at Dalhousie University, Canada.

Lambert Engelbrecht is Senior Lecturer at the Department of Social Work, University of Stellenbosch, South Africa. 